\title{
Health-Related Quality-of-Life and Associated Factors Among Post-Partum Women in Arba Minch Town
}

\author{
Yirgalem Tola' \\ Gistane Ayele (iD ${ }^{2}$ \\ Negussie Boti $\mathbb{D}^{2}$ \\ Manaye Yihune $\mathbb{D}^{2}$ \\ Firdawek Gethahun $\mathbb{D D}^{2}$ \\ Zeleke Gebru ${ }^{2}$ \\ 'Arba Minch Health Science College, \\ Department of Midwifery, Arba Minch, \\ Ethiopia; ${ }^{2}$ Arba Minch University, College \\ of Medicine \& Health Sciences, School of \\ Public Health, Arba Minch, Ethiopia
}

Correspondence: Negussie Boti $\mathrm{Tel}+25 \mathrm{I}-920997752$

Email Hanehalid@gmail.com
Background: It is generally accepted that pregnancy and childbirth are natural physiological processes. However, these significantly affect the quality of mothers' lives. Little is known about the level of quality-of-life and associated factors among postpartum women in Ethiopia, particularly in the study area.

Methods: A community-based cross-sectional study was conducted among 409 randomly selected post-partum women who were living in Arba Minch town. Systematic random sampling was employed to select the study participants. The standard quality-of-life assessment tool which is known as the short-form SF 36 tool was used to assess health-related quality-of-life. The logistic regression model was used to identify associated factors. Statistically significant variables at a $p$-value $<0.25$ in the bi-variable analysis were candidate variables for multi-variable analysis and statistical significance which was declared at a $p$-value $<0.05$.

Results: Among the study participants, 255 (62.3\%) had lower level health-related qualityof-life (HRQoL). About $46.2 \%$ of the study participants had lower physical HRQoL and about $79 \%$ of the study participants had lower mental HRQoL. The overall mean score of HRQoL was $45.15( \pm 8.13)$. Factors associated with lower overall HRQoL were age group 17-24 years $(\mathrm{AOR}=2.73,95 \% \mathrm{CI}=1.22-6.10)$, no formal education [AOR 2.02, 95\% CI (1.05-3.89)], and cesarean delivery $(\mathrm{AOR}=0.49,95 \% \mathrm{CI}=0.24-0.97)$. A factor associated with lower physical HRQoL was cesarean delivery ( $\mathrm{AOR}=0.34,95 \% \mathrm{CI}=0.13-0.88$ ). Factors associated with lower mental HRQoL were age group 17-24 (AOR=3.37, 95\% $\mathrm{CI}=1.60-7.04)$, not receiving antenatal care $(\mathrm{AOR}=3.65,95 \% \mathrm{CI}=1.45-9.16)$, and having postpartum depression $(\mathrm{AOR}=2.27,95 \% \mathrm{CI}=1.30-3.93)$.

Conclusion: The results suggest that the majority of post-partum women had a lower HRQoL, particularly women's mental health was compromised. In this study, a suggestion is made that the respective bodies need to give particular attention to mothers during the post-partum period to prevent poor quality-of-life.

Keywords: post-partum women, health-related quality-of-life

\section{Background}

Pregnancy and childbirth are natural physiological processes that involve a tremendous change in the physiology, anatomy, and psychology of the mother. ${ }^{1,2}$ However, pregnancy and birth may impair women's physical, mental, and social health. ${ }^{3-5}$ Particularly after childbirth physical and mental illnesses that result directly from pregnancy or childbirth have a significant impact on women's quality-of-life. $^{6-8}$ Quality-of-life is an individual's perception of their life in the 
context of the culture and value systems in which they live and about their goals, expectations, standards, and concerns. $^{9}$

Many women usually have little information about the long-lasting physical and mental health problems that may result as a consequence of pregnancy, childbirth, and puerperium; therefore, they are unprepared when they face such problems. As a result, their quality-of-life will be compromised for a prolonged period. . $^{3,10-12}$

According to several studies, impaired woman's health-related quality-of-life (HRQoL) after childbirth limits daily activity, decreases self-care ability, impairs child care, causes discontinuation of breastfeeding and the early introduction of solid food to an infant's diet, and increases medical care costs. A mother's heHRQoL also affects the health and well-being of the child, with long-term consequences on the child's psychological development. ${ }^{13-16}$

Socio-demographic (age, educational status, marital status, wealth), obstetric (parity, mode of delivery), and psychosocial (depressive disorder) factors have been identified to be strongly associated with HRQoL postpartum. ${ }^{17-20}$

During the postpartum period, many studies have focused on identifying and quantifying problems such as postpartum depression, sleeping problems, genital infections, breast problems, and anemia. However, the finding from such studies does not fully describe maternal physical, mental, and social health. Therefore, this study assessed the level of HRQoL and associated factors among postpartum women using a short-form (SF-36) instrument.

\section{Methods Study Setting}

This study was conducted in Arba Minch town. Arba Minch town is the administrative center of Gamo Zone. Gamo zone is one of the 14 Zones in the Southern Nations, Nationalities, and People's Regional State (SNNPR) of Ethiopia. Arba Minch town is located $435 \mathrm{~km}$ southwest of Addis Ababa, the capital city of Ethiopia, and $275 \mathrm{~km}$ southwest of Hawassa, the capital city of Southern Nations and Nationalities Regional State. Currently, in Arba Minch town, there are three public health centers and one public hospital.

\section{Study Design}

A community-based cross-sectional study was carried out from April 16 to May 16, 2020 to determine the magnitude of HRQoL and associated factors among postpartum women in Arba Minch town.

\section{Source and Study Populations}

All postpartum women aged 15-49 years who were living in Arba Minch town were the source population. The study population were randomly selected postpartum women aged 15-49 years who were living in Arba Minch town. Postpartum women who were severely ill, those who had a mental illness, and those who had been living in the study area for less than 6 months were excluded.

\section{Sample Size Determination}

The sample size was calculated using the single population approach and it was calculated using Epi Info version 7.02 statistical software package with the assumption of $95 \%$ confidence level $(Z \alpha / 2=1.96), 80 \%$ power $(Z \beta=0.84)$, and $\mathrm{P}=50 \%$ of postpartum women who have a lower HRQoL, since there is no similar study conducted among postpartum women.

$$
\left(\mathrm{n}=\frac{Z \alpha / 2^{2} p q}{d^{2}}\right)=\frac{\left(1.96^{2}\right) *(0.5 * 0.5)}{0.05^{2}}=385
$$

Considering a $10 \%$ non-response rate and the final sample size was 424 .

Where $n=$ required sample size, $Z \alpha / 2=$ critical value for normal distribution at $95 \%$ confidence level which equals 1.96 (Z-value at $\alpha=0.05$ ), $p=$ proportion of women with lower HRQoL of $50 \%, \mathrm{~d}=$ margin of error of $5 \%$.

\section{Sampling Procedure}

The target participants for this study were women who had given birth in the past 6 months in Arba Minch town. In the town, there are 11 kebeles. Among these, about $35 \%{ }^{4}$ od kebeles were randomly selected using the lottery method as representative. Then, based on the preceding 6 months' total birth report obtained from the town health bureau; the sample was allocated proportionally to each Kebele. Finally, the participants were selected through systematic random sampling using the health extension workers' birth register as a frame. Systematic sampling was preferred for its simplicity to apply. From the register list, all women were selected (Figure 1).

The dependent variable for this study is HRQoL, whereas independent variables include socio-demographic characteristics such as age, educational status, marital status, employment, wealth index, and obstetrics factors such as antenatal care follow-up, mode of delivery, parity, hospital admission during pregnancy, and after birth, duration 


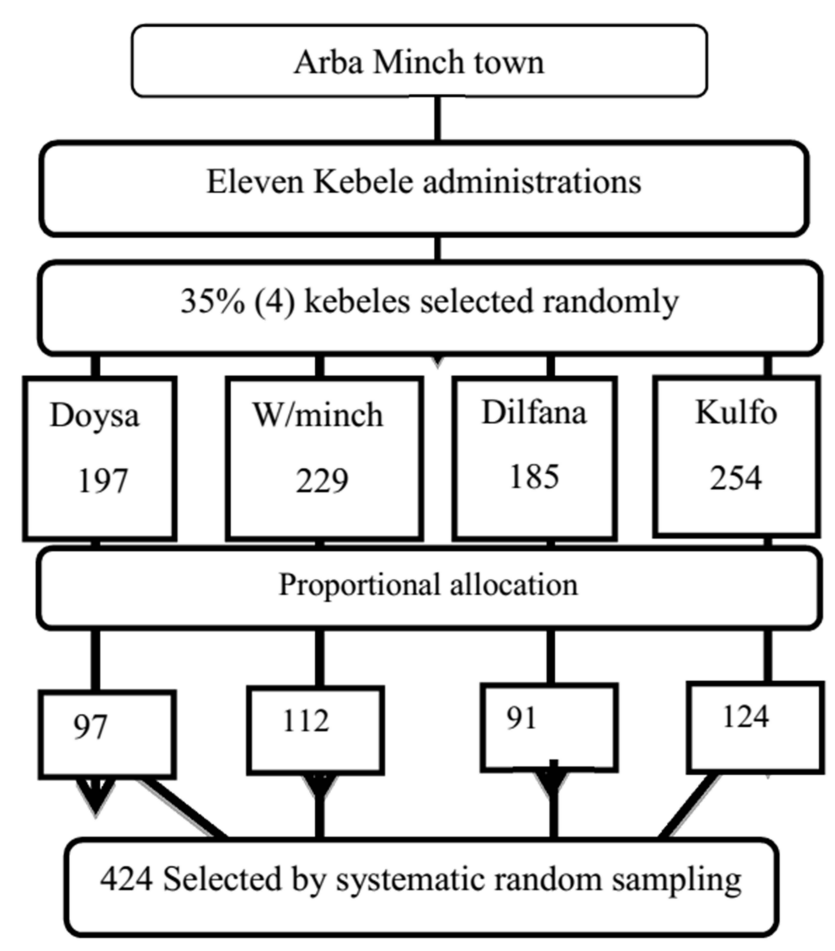

Figure I The diagrammatic presentation of the sampling procedures of postpartum women who were selected to participate in the study in 2020 .

since delivery, place of birth, and psychological factor for postpartum depression.

\section{Measurements}

Domain scores were calculated by summing up each item under each domain. Then each raw scale score was transformed from 0 to 100 (0-100 scale) by using the formula of transformed scale $=\frac{\text { actual raw score-lower possible score }}{\text { possible raw score range }} \times 100 .^{21}$

Physical HRQoL (PCS) mean score is the arithmetic average of the transformed scores of physical functioning, role physical, bodily pain, and general health domains. ${ }^{21}$

Mental HRQoL (MSC) mean score is the arithmetic average of the transformed scores of social functioning, mental health, role emotional, and vitality domains. ${ }^{21}$

Overall HRQoL mean score is the arithmetic average of the transformed score of the eight domains. ${ }^{22}$

Higher HRQoL was defined as participants who scored greater than or equal to the standardized mean value of $50 .^{23}$

Lower HRQoL was defined as participants who scored less than the standardized mean value of $50 .^{23}$

Wealth Index is a composite measure of household cumulative living standard, and it was calculated by using data on household ownership of selected assets, like various household assets and means of transportation. Then, it was categorized as lowest quintile, second quintile, middle quintile, fourth quintile, and highest quintile. The lowest quintile signifies lower wealth whereas the highest quintile signifies higher wealth status.

Postpartum Partum depression is assessed by using the Edinburgh Postnatal Depression Scale (EPDS). According to the EDPS, study participants who scored $\geq 13$ are considered as having postpartum depression. ${ }^{24}$

\section{Data Collection Procedure}

Data were collected using a structured questionnaire adapted from different peer-reviewed published works. $^{25-30}$ A structured pre-tested interviewer administered questionnaire was developed in English and then translated into Amharic language for simplicity and then back translated to English language for its consistency by two different language expert individuals who speak both English and Amharic fluently. The questionnaire has three parts: sociodemographics, obstetrics-related characteristics, and qualityof-life health-related characteristics. HRQoL was measured using MOS SF-36, which was validated and translated for Ethiopia by a validation study. ${ }^{31}$ The SF-36 questionnaire is capable to evaluate both the physical and mental components of HRQoL; this tool has 36 items, eight domains, and two component summaries. The first two items measure the overall perception of the quality-of-life and change in the overall health status. The SF-36 questionnaires assess eight dimensions of HRQoL, which relate to the physical and mental components of the individual's health perception. Specifically, the domains "physical functioning" (10 items), "role physical", which means role limitation due to physical health problems (4 items), "bodily pain" (2 items), and "general health" (5 items) are more related to the physical component, whereas the domains "vitality/energy" (4 items), "social functioning (2 items), "role emotional", which means role limitations due to emotional problems (3 items), and general "mental health" (5 items) are more related to the psychological component. Possible scores for each domain range from 0 (corresponding to the worst possible state) to 100 (corresponding to the best possible state). ${ }^{21}$ The 10 questions of the Edinburgh postnatal depression scale (EPDS) were used to assess patients at risk of postnatal depression. ${ }^{24}$ It indicates how the mother has felt during the previous 7 days. The EPDS generated sensitivity and specificity of $78.9 \%$ and $75.3 \%$, respectively, according to a validation study in Addis Ababa. ${ }^{24}$ The wealth index was assessed using the tool adapted from the Ethiopian Demographic and Health Survey (EDHS) wealth index assessment questionnaire. 
Four diploma nurses were recruited as data collectors and they were trained for 2 days on information about the research objective, eligible study subjects, data collection tools and procedures, and interview methods. Information regarding the coronavirus and necessary precautions to take while collecting data to prevent coronavirus transmission was also given. The data collection task was carried out through home-to-home visits and the data collectors wore masks, kept a physical distance, washed their hands, and used hand sanitizer. Besides this, data collectors gave awareness training on coronavirus in the community in collaboration with health extension workers in each selected kebele.

\section{Data Quality Control}

Pretesting of the questionnaire was done on $5 \%$ of the sample at Merab Abaya district who were not included in the study; that was a week before commencement of the actual data collection. Based on the pretest, a questionnaire was corrected to ensure clarity, wording, and logic sequence and skip patterns. Data collectors and supervisor were trained for 1 day on objectives of the study, how to keep confidentiality of information, the contents of the questionnaire, filling data collection format, and data quality management by the principal investigator. At the end of each day, questionnaires were reviewed and cross-checked for completeness, accuracy, and consistency by the supervisor and principal investigator and corrective measures were taken. The overall activity was supervised by the principal investigator of the study.

\section{Method of Data Analysis}

The collected data were checked for completeness, coded, and entered into Epidata version 3.1. The data were then exported to SPSS version 25, and cleaned to make it ready for analysis. Five categories of wealth (quintiles) were developed using principal component analysis (PCA). For SF-36 questionnaires, the first reverse score for the 10 items was done and then the raw score was computed for the eight domains which were then cleaned to a Transformed scale. Physical HRQoL (PCS) mean was computed from physical functioning, role physical, bodily pain, and general health domain transformed score. Mental HRQoL (MCS) mean was computed from social functioning, mental health, vitality, and role emotional domain transformed score. The overall HRQoL mean was computed from the eight domains transformed score. Using the standardized mean score of 50; the overall HRQoL,
Physical HRQoL, and Mental HRQoL were dichotomized into higher and lower HRQoL. Binary logistic regression analysis was employed to examine the statistical association between the overall HRQoL, physical HRQoL, and mental HRQoL with every single independent variable. We fitted both simple and multivariable logistic regression models. Variables with a $P$-value $<0.25$ at the simple logistic regression analysis were considered a candidate to multivariable logistic regression analysis. In the multivariable logistic regression model, we considered variables with a $P$-value $<0.05$ as significantly associated variables with the outcome. The model fitness was checked, and we found the Hosmer and Lemeshow's goodness-of-fit test not significant. This indicates the observed model does not significantly differ from the expected model. This eventually depicted, the whole model was fit enough to explain the distribution. Multicollinearity was assured using the checked correlation matrix.

\section{Results \\ Socio-Demographic Characteristics of Respondents}

Among 424 post-partum women, 409 post-partum women were interviewed. This gives a response rate of $96.46 \%$. More than half $(253,61.9 \%)$ of the respondents belonged to the age group of 17-24 with a Mean \pm SD of $28.09 \pm 5.65$ years. Regarding marital status, 315 (77\%) were married, $131(32 \%)$ had more than secondary educational status, as to occupational status $154(37.7 \%)$ were government employees, followed by housewives $(129,31.5 \%)$, and $93(22.8 \%)$ participants belonged in the fourth quintile as to wealth index (Table 1).

\section{Obstetric Characteristics of Respondents}

Three hundred and twenty-three (79.0\%) of the subjects were multiparous, while $86(21.0 \%)$ were Prim parous. About 372 (91.0\%) mothers visited the ANC clinic. Regarding the place of birth, more than half 220 (53.8\%) gave birth at the Hospital, with 30 (7.3\%) of them delivered by cesarean section. Furthermore, $35(8.6 \%)$ experienced the loss of their baby, and $60(14.7 \%)$ reported having a hospitalization history during pregnancy for a pregnancyrelated problem, and 45 (11.0\%) after birth (Table 2).

\section{Health-Related Quality-of-Life}

The finding of this study reveals that $255(62.3 \%)$ had lower level health-related quality of life (HRQoL). About $46.2 \%$ of 
Table I Socio-Demographic Characteristics Distribution of Study Participants at Arba Minch Town in 2020 ( $n=409)$

\begin{tabular}{|c|c|c|c|}
\hline \multicolumn{2}{|c|}{ Respondents Characteristics } & \multirow{4}{*}{$\begin{array}{l}\text { Frequency } \\
253 \\
100 \\
56\end{array}$} & \multirow{2}{*}{$\begin{array}{l}\text { Percent } \\
\text { (\%) }\end{array}$} \\
\hline Age & $17-24$ & & \\
\hline & $25-34$ & & 24.4 \\
\hline & $35-45$ & & 13.7 \\
\hline \multirow[t]{5}{*}{ Marital status } & Never married & 21 & 5.1 \\
\hline & Married & 315 & 77.0 \\
\hline & Living together & 33 & 8.1 \\
\hline & Divorced & 23 & 5.6 \\
\hline & Widowed & 17 & 4.2 \\
\hline \multirow[t]{4}{*}{$\begin{array}{l}\text { Educational } \\
\text { status }\end{array}$} & $\begin{array}{l}\text { No formal } \\
\text { education }\end{array}$ & 83 & 20.3 \\
\hline & Primary & 69 & 16.9 \\
\hline & Secondary & 126 & 30.8 \\
\hline & Above Secondary & $|3|$ & 32.0 \\
\hline \multirow{5}{*}{$\begin{array}{l}\text { Occupational } \\
\text { status }\end{array}$} & Student & 58 & 14.2 \\
\hline & Housewife & 129 & 31.5 \\
\hline & $\begin{array}{l}\text { Government } \\
\text { employee }\end{array}$ & 154 & 37.7 \\
\hline & Private employee & 50 & 12.2 \\
\hline & Other* & 18 & 4.4 \\
\hline \multirow{5}{*}{$\begin{array}{l}\text { Wealth index } \\
\text { quintile }\end{array}$} & Lowest & 79 & 19.3 \\
\hline & Second & 84 & 20.5 \\
\hline & Middle & 85 & 20.8 \\
\hline & Fourth & 93 & 22.8 \\
\hline & Highest & 68 & 16.6 \\
\hline
\end{tabular}

Notes: *daily laborers, handcraft worker.

the study participants had lower physical HRQoL and about $79 \%$ of the study participants had lower mental HRQoL. From the eight domains, the lowest mean score was observed in the role emotional dimension with Mean \pm SD of 38.09 \pm 21.34 , whereas the highest Mean \pm SD score in the vitality dimension was 51.40 \pm 7.69. The physical component summary (PCS) Mean \pm SD score was higher in Mean \pm SD score (49.52 \pm 9.34$)$ when compared with the mental component summary (MCS) Mean \pm SD score of 40.79 \pm 10.90 (Table 3).

\section{Factors Associated with Overall Health-Related Quality-of-Life}

A binary logistic regression was run to identify candidate variables for multivariable logistic regression analysis. Those variables were $p$-value $<0.25$ during binary regression analysis and biologically plausible variables were selected as a candidate variable for multivariable logistic regression analysis. Thus, in the binary logistic regression analysis variables
Table 2 Obstetric Characteristics of Study Participant at Arba Minch Town in $2020(n=409)$

\begin{tabular}{|c|c|c|c|}
\hline \multicolumn{2}{|c|}{ Respondents Characteristics } & \multirow{2}{*}{$\begin{array}{l}\text { Frequency } \\
243 \\
166\end{array}$} & \multirow{2}{*}{$\begin{array}{l}\text { Percent } \\
\text { (\%) } \\
59.4 \\
40.6\end{array}$} \\
\hline $\begin{array}{l}\text { Duration since } \\
\text { delivery }\end{array}$ & $\begin{array}{l}\leq 3 \text { months } \\
>3 \text { months }\end{array}$ & & \\
\hline Parity & $\begin{array}{l}\text { Prim parous } \\
\text { Multiparous }\end{array}$ & $\begin{array}{l}86 \\
323\end{array}$ & $\begin{array}{l}21.0 \\
79.0\end{array}$ \\
\hline State of last pregnancy & $\begin{array}{l}\text { Planned } \\
\text { Unplanned }\end{array}$ & $\begin{array}{l}352 \\
57\end{array}$ & $\begin{array}{l}86.1 \\
13.9\end{array}$ \\
\hline Received ANC & $\begin{array}{l}\text { Yes } \\
\text { No }\end{array}$ & $\begin{array}{l}372 \\
37\end{array}$ & $\begin{array}{l}91.0 \\
9.0\end{array}$ \\
\hline ANC adequacy & $\begin{array}{l}\text { Non-adequate } \\
\text { Adequate* }\end{array}$ & $\begin{array}{l}170 \\
202\end{array}$ & $\begin{array}{l}45.7 \\
54.3\end{array}$ \\
\hline Place of birth & $\begin{array}{l}\text { Home } \\
\text { Health center } \\
\text { Hospital }\end{array}$ & $\begin{array}{l}41 \\
148 \\
220\end{array}$ & $\begin{array}{l}10.0 \\
36.2 \\
53.8\end{array}$ \\
\hline Mode of delivery & $\begin{array}{l}\text { Vaginal } \\
\text { Cesarean }\end{array}$ & $\begin{array}{l}379 \\
30\end{array}$ & $\begin{array}{l}92.7 \\
7.3\end{array}$ \\
\hline Birth outcome & $\begin{array}{l}\text { Alive } \\
\text { Dead }\end{array}$ & $\begin{array}{l}374 \\
35\end{array}$ & $\begin{array}{l}91.4 \\
8.6\end{array}$ \\
\hline $\begin{array}{l}\text { History of hospital } \\
\text { admission during } \\
\text { pregnancy }\end{array}$ & $\begin{array}{l}\text { Yes** } \\
\text { No }\end{array}$ & $\begin{array}{l}60 \\
349\end{array}$ & $\begin{array}{l}14.7 \\
85.3\end{array}$ \\
\hline $\begin{array}{l}\text { History of hospital } \\
\text { admission after birth }\end{array}$ & $\begin{array}{l}\text { Yes } \\
\text { No }\end{array}$ & $\begin{array}{l}45 \\
364\end{array}$ & $\begin{array}{l}11.0 \\
89.0\end{array}$ \\
\hline Postpartum depression & $\begin{array}{l}\text { Depressed } \\
\text { Not depressed }\end{array}$ & $\begin{array}{l}88 \\
321\end{array}$ & $\begin{array}{l}21.5 \\
78.5\end{array}$ \\
\hline
\end{tabular}

Notes: *Adequate ANC is a woman who had received antenatal care according to Ethiopian guidelines. **Hospital admission due to other than childbirth.

like age of respondents, educational level, wealth index, state of last pregnancy, receiving ANC follow-up, place of birth, mode of delivery, birth outcome, and history of hospital admission after birth were selected variables for multivariable logistic regression analysis.

In multivariable logistic regression analysis showed that age of respondents, educational level, and mode of delivery were variables that are found to have a statistically significant association with the lower overall HRQoL. Those post-partum women aged between 17-24 years were 2.73-times more likely to have lower overall HRQoL compared to the age group between 35-45 years $(\mathrm{AOR}=2.73 ; 95 \% \quad \mathrm{CI}=1.22-6.10)$. Those post-partum women who did not attend formal education were 2.02times more likely to have lower overall HRQoL compare 
Table 3 Mean Score of SF-36 HRQoL and the Two-Component Summary Score of Study Participant at Arba Minch Town in 2020

\begin{tabular}{|l|l|l|}
\hline SF-36 HRQoL & Mean \pm SD & $\mathbf{9 5 \% ~ C l ~}$ \\
\hline Physical functioning (PF) & $46.97 \pm 10.06$ & $45.28-47.23$ \\
Role physical (RP) & $42.30 \pm 14.46$ & $40.28-43.00$ \\
Bodily pain (BP) & $50.93 \pm 9.06$ & $49.34-51.10$ \\
General health (GH) & $49.24 \pm 9.49$ & $47.61-49.46$ \\
Vitality (VT) & $51.40 \pm 7.69$ & $50.65-52.14$ \\
Social functioning (SF) & $48.21 \pm 10.68$ & $47.18-49.25$ \\
Role emotional (RE) & $38.09 \pm 21.34$ & $34.62-38.77$ \\
Mental health (MH) & $40.08 \pm 13.02$ & $37.42-39.96$ \\
Physical Component Summary (PCS) & $49.52 \pm 9.34$ & $48.61-50.43$ \\
Mental Component Summary (MCS) & $40.79 \pm 10.90$ & $39.37-41.85$ \\
Overall HRQoL & $45.15 \pm 8.13$ & $44.36-45.94$ \\
\hline
\end{tabular}

to those women who had attended above secondary $(\mathrm{AOR}=2.02 ; 95 \% \mathrm{CI}=1.05-3.89)$. On the other hand, those post-partum women who were delivered by cesarean section were 59\% less likely to have lower overall HRQoL compare to those women who give by SVD $(\mathrm{AOR}=0.41$; 95\% CI=0.17-0.96)) (Table 4).

\section{Factors Associated with Mental Health-Related Quality-of-Life Among Post-Partum Women}

Multivariable logistic regression analysis shows that age of the respondents, receiving ANC follow-up during their pregnancy, and those women who had postpartum depression were significantly associated with lower mental HRQoL among postpartum women. Women who were in the age group from 1724 years were 3.37-times more likely to have lower mental HRQoL with $\mathrm{AOR}=3.56 ; 95 \% \mathrm{CI}=1.60-7.04$, whereas women who had not received ANC were 3.73-times more likely to have lower mental health HRQoL with $\mathrm{AOR}=3.73$; 95\% CI=1.45-9.16. Similarly, women who had postpartum depression (PPD) were 2.00-times more likely to have lower mental HRQoL with $\mathrm{AOR}=2.00 ; \quad 95 \% \quad \mathrm{CI}=1.30-3.93$ (Table 5).

\section{Factors Associated with Physical Health-Related Quality-of-Life Among Post-Partum Women}

Multivariable logistic regression analysis shows that the model of delivery of the recent baby was found as an independent predictor of physical HRQoL among postpartum women. Those post-partum women who were delivered by cesarean section were $66 \%$ less likely to have lower physical HRQoL compared to those women who give birth by SVD $(\mathrm{AOR}=0.34,95 \% \mathrm{CI}=0.13-0.88)$ (Table 6).

\section{Discussion}

This research aimed to assess HRQoL and associated factors among post-partum women in Arba Minch town in Southern parts of Ethiopia. The overall HRQoL mean score in this study was $45.15 \pm 8.13$. Age of respondents, education status, ANC, mode of delivery, and having postpartum depression were found to have a statistically significant association with lower HRQoL.

The overall HRQoL mean score in this study is comparable with a study conducted in Kuwait, with a mean score of 53.7, but it is lower than studies conducted in Iran (66.32 \pm 13.7$)$, Spain (71.94 \pm 17.48$)$, and Brazil (86.86 $\pm 10.6) .{ }^{17,27,32}$ The difference could be due to the socioeconomic disparity of study participants. In this study, the majority of the study participants had low socioeconomic status, but previous studies were conducted in a higher socioeconomic status. A higher socioeconomic status favors a higher quality-of-life. Another difference might be due to differences in the study population. In this study, we including women who gave birth in the last 6 months, but the study conducted in Spain included women who give birth in the year before. The discrepancy in the two studies (Brazil and Iran) might be due to a variation in the tool used to assess the quality-of-life. In this study, we used SF-36 questionnaires, but studies conducted in Brazil and Iran used the World Health Organization Quality-ofLife Assessment-Bref (WHOQoL-Bref) tool.

Age was shown to have an association with HRQoL; women who were in the age group 17-24 were more likely to have lower level HRQoL in this study. From this, the majority of them in this age group were prim parous women who were less experienced, new to pregnancy, birth, and postpartum life, so were less likely to cope with pregnancy, birth, and postpartum related changes and this age group are more likely to develop postpartum depression leading to lower-level mental HRQoL. However, the current finding is contrary to the study conducted in the Netherlands and the variation could be due to socio-demographic differences for western women to become pregnant later in their reproductive life. ${ }^{30}$

In the current finding education status showed an association with HRQoL. This means women who had no formal education were more likely to have lower HRQoL. This finding is related to prior studies conducted 
Table 4 Binary and Multivariable Logistic Regression Analysis for Factors Associated with Overall HRQoL of Study Participants at Arba Minch Town in $2020(n=409)$

\begin{tabular}{|c|c|c|c|c|c|c|c|}
\hline Variable & Categories & $\begin{array}{l}\text { Lower } \\
\text { HRQoL (\%) }\end{array}$ & $\begin{array}{l}\text { Higher } \\
\text { HRQoL (\%) }\end{array}$ & COR $(95 \% \mathrm{Cl})$ & $P$-value & AOR $(95 \% \mathrm{Cl})$ & $P$-value \\
\hline Age of respondents & $\begin{array}{l}17-24 \\
25-34 \\
35-45\end{array}$ & $\begin{array}{l}90(75.0) \\
133(57.1) \\
32(57.1)\end{array}$ & $\begin{array}{l}30(25.0) \\
100(42.9) \\
24(42.9)\end{array}$ & $\begin{array}{l}2.25(1.15-4.40) \\
0.99(0.55-1.79) \\
1\end{array}$ & $\begin{array}{l}0.014^{*} \\
0.951\end{array}$ & $\begin{array}{l}2.73(1.22-6.10) \\
0.98(0.5 \mathrm{I}-1.86) \\
\mathrm{I}\end{array}$ & $\begin{array}{l}0.014^{*} \\
0.951\end{array}$ \\
\hline Educational status & $\begin{array}{l}\text { No formal } \\
\text { education } \\
\text { Primary } \\
\text { Secondary } \\
\text { Above secondary }\end{array}$ & $\begin{array}{l}57(68.7) \\
44(63.8) \\
78(61.9) \\
76(58)\end{array}$ & $\begin{array}{l}26(31.3) \\
25(36.2) \\
48(38.1) \\
55(42)\end{array}$ & $\begin{array}{l}\mathrm{I} .58(0.88-2.83) \\
\mathrm{I} .27(0.69-2.32) \\
\mathrm{I} .17(0.7 \mathrm{I}-\mathrm{I} .93) \\
\mathrm{I}\end{array}$ & $\begin{array}{l}0.118 \\
0.430 \\
0.525\end{array}$ & $\begin{array}{l}2.02(1.05-3.89) \\
\text { I.49 (0.74-2.98) } \\
\text { I.46( } 0.84-2.55) \\
\mathrm{I}\end{array}$ & $\begin{array}{l}0.035^{*} \\
0.256 \\
0.171\end{array}$ \\
\hline Wealth index & $\begin{array}{l}\text { Lowest } \\
\text { Second } \\
\text { Middle } \\
\text { Fourth } \\
\text { Highest }\end{array}$ & $\begin{array}{l}50(63.3) \\
49(58.3) \\
52(61.2) \\
57(61.3) \\
47(69.1)\end{array}$ & $\begin{array}{l}29(36.7) \\
35(41.7) \\
33(38.8) \\
36(38.7) \\
21(30.9)\end{array}$ & $\begin{array}{l}0.77(0.38-1.53) \\
0.62(0.31-1.22) \\
0.70(0.35-1.38) \\
0.70(0.36-1.37) \\
1\end{array}$ & $\begin{array}{l}0.458 \\
0.172 \\
0.308 \\
0.306\end{array}$ & $\begin{array}{l}1.02(0.46-2.23) \\
0.64(0.30-1.37) \\
0.72(0.34-1.5 \mathrm{I}) \\
0.63(0.30-1.32) \\
\mathrm{I}\end{array}$ & $\begin{array}{l}0.957 \\
0.259 \\
0.389 \\
0.225\end{array}$ \\
\hline Duration since delivery & $\begin{array}{l}\leq 3 \text { Months } \\
>3 \text { Months }\end{array}$ & $\begin{array}{l}155(63.8) \\
100(60.2)\end{array}$ & $\begin{array}{l}88(36.2) \\
66(39.8)\end{array}$ & $\begin{array}{l}\text { I.I6 (0.77-I.74) } \\
\mathrm{I}\end{array}$ & 0.248 & $\begin{array}{l}1.20(0.76-1.91) \\
1\end{array}$ & 0.429 \\
\hline Parity & $\begin{array}{l}\text { Prim-para } \\
\text { Multi-para }\end{array}$ & $\begin{array}{l}55(64.0) \\
200(6 I .9)\end{array}$ & $\begin{array}{l}31(36.0) \\
123(38.1)\end{array}$ & $\begin{array}{l}1.09(0.66-1.78) \\
1\end{array}$ & 0.209 & $\begin{array}{l}1.60(0.83-3.08) \\
\mathrm{I}\end{array}$ & 0.160 \\
\hline Pregnancy state & $\begin{array}{l}\text { Planned } \\
\text { Unplanned }\end{array}$ & $\begin{array}{l}224(63.6) \\
31(54.4)\end{array}$ & $\begin{array}{l}128(36.4) \\
26(45.6)\end{array}$ & $\begin{array}{l}\text { I } \\
0.68(0.38-1.19)\end{array}$ & 0.183 & $\begin{array}{l}\text { I } \\
0.58(0.30-1.12)\end{array}$ & 0.107 \\
\hline Adequate ANC follow-up & $\begin{array}{l}\text { Yes } \\
\text { No }\end{array}$ & $\begin{array}{l}225(60.5) \\
30(8 I . I)\end{array}$ & $\begin{array}{l}147(39.5) \\
7(18.9)\end{array}$ & $2.80(1.19-6.54)$ & 0.017 & $\begin{array}{l}\text { I } \\
2.5 I(0.93-6.74)\end{array}$ & 0.067 \\
\hline Place of birth & $\begin{array}{l}\text { Home } \\
\text { Health center } \\
\text { Hospital }\end{array}$ & $\begin{array}{l}30(73.2) \\
97(65.5) \\
128(58.2)\end{array}$ & $\begin{array}{l}\text { II }(26.8) \\
51(34.5) \\
92(41.8)\end{array}$ & $\begin{array}{l}1.36(0.88-2.10) \\
1.96(0.93-4.11) \\
I\end{array}$ & $\begin{array}{l}0.075 \\
0.156\end{array}$ & $\begin{array}{l}\mathrm{I} .33(0.82-2.16) \\
\mathrm{I} .6 \mathrm{I}(0.65-4.0 \mathrm{I}) \\
\mathrm{I}\end{array}$ & $\begin{array}{l}0.239 \\
0.302\end{array}$ \\
\hline Mode of delivery & $\begin{array}{l}\text { Vaginal } \\
\text { Cesarean section }\end{array}$ & $\begin{array}{l}243(64.1) \\
12(40.0)\end{array}$ & $\begin{array}{l}136(35.9) \\
18(60.0)\end{array}$ & $\begin{array}{l}\text { I } \\
0.37(0.17-0.79)\end{array}$ & 0.007 & $\begin{array}{l}\text { I } \\
0.41(0.17-0.96)\end{array}$ & $0.040 *$ \\
\hline $\begin{array}{l}\text { History of Hospital } \\
\text { admission after birth }\end{array}$ & $\begin{array}{l}\text { Yes } \\
\text { No }\end{array}$ & $\begin{array}{l}24(53.3) \\
231(63.5)\end{array}$ & $\begin{array}{l}21(46.7) \\
133(36.5)\end{array}$ & $\begin{array}{l}0.65(0.35-1.22) \\
1\end{array}$ & 0.188 & $\begin{array}{l}0.68(0.34-1.36) \\
I\end{array}$ & 0.285 \\
\hline Postpartum depression & $\begin{array}{l}\text { Depressed } \\
\text { Not depressed }\end{array}$ & $\begin{array}{l}56(63.6) \\
199(62.0)\end{array}$ & $\begin{array}{l}32(36.4) \\
122(38.0)\end{array}$ & $\begin{array}{l}0.93(0.57-1.52) \\
I\end{array}$ & 0.178 & $\begin{array}{l}0.90(0.53-1.53) \\
1\end{array}$ & 0.709 \\
\hline
\end{tabular}

Notes: * a statistically significant variable at $p<0.05$ in multivariable logistic regression analysis.

in India and Spain. The possible reason might be because those women who had no formal education are less likely to attend ANC, more likely to give birth at home, less likely to seek healthcare immediately until complication arise, and more likely to have severe maternal outcome. ${ }^{25,27,33}$ Another possible reason might be that educated women would have control over their economy and therefore be more likely autonomous to decide on their healthcare as compared with those who were uneducated. This implies that a large number of women who had no formal education may suffer from preventable diseases due to a lack of information. Therefore, careful attention should be given to those women by the government and other concerned bodies.

Mode of delivery is another factor that showed a statistical association with health-related quality-of-life so such cesarean delivery identified to have a positive association with HRQoL in the current finding. The reason might be women who have given birth by operation have a higher possibility to receive optimal healthcare and a full package of postnatal care which favors rapid recovery and higher HRQoL. Socio-cultural factors could 
Table 5 Binary and Multivariable Logistic Regression Analysis for Factors Associated with Mental HRQoL at Arba Minch Town in 2020 $(n=409)$

\begin{tabular}{|c|c|c|c|c|c|c|c|}
\hline Variables & Categories & $\begin{array}{l}\text { Lower MCS } \\
\text { HRQoL (\%) }\end{array}$ & $\begin{array}{l}\text { Higher MCS } \\
\text { HRQoL (\%) }\end{array}$ & COR $(95 \% \mathrm{Cl})$ & $p$-value & AOR (95\% Cl) & $p$-value \\
\hline Age & $\begin{array}{l}17-24 \\
25-34 \\
35-45\end{array}$ & $\begin{array}{l}73(60.8) \\
93(39.9) \\
17(30.4)\end{array}$ & $\begin{array}{l}47(39.2) \\
140(60.1) \\
39(69.6)\end{array}$ & $\begin{array}{l}3.56(\mathrm{I} .8 \mathrm{I}-0.70) \\
\mathrm{I} .52(0.8 \mathrm{I}-2.85) \\
\mathrm{I}\end{array}$ & $\begin{array}{l}0.001 \\
0.19\end{array}$ & $\begin{array}{l}3.37(1.60-7.04) \\
1.51(0.77-2.97) \\
I\end{array}$ & $\begin{array}{l}0.001 * \\
0.22\end{array}$ \\
\hline Educational status & $\begin{array}{l}\text { No formal education } \\
\text { Primary } \\
\text { Secondary } \\
\text { Above secondary }\end{array}$ & $\begin{array}{l}40(48.2) \\
39(56.5) \\
48(38.1) \\
56(42.7)\end{array}$ & $\begin{array}{l}43(51.8) \\
30(43.5) \\
78(61.9) \\
75(57.3)\end{array}$ & $\begin{array}{l}1.24(0.71-2.16) \\
1.74(0.96-3.13) \\
0.82(0.50-1.35) \\
1\end{array}$ & $\begin{array}{l}0.24 \\
0.04 \\
0.72\end{array}$ & $\begin{array}{l}1.37(0.7 \mid-2.67) \\
2.08(0.98-4.42) \\
0.97(0.55-1.69) \\
I\end{array}$ & $\begin{array}{l}0.34 \\
0.06 \\
0.92\end{array}$ \\
\hline $\begin{array}{l}\text { Occupational } \\
\text { status }\end{array}$ & $\begin{array}{l}\text { Non-employed } \\
\text { Employed }\end{array}$ & $\begin{array}{l}94(50.3) \\
89(40.1)\end{array}$ & $\begin{array}{l}93(49.7) \\
133(59.9)\end{array}$ & $\begin{array}{l}\text { I } \\
0.66(0.44-0.98)\end{array}$ & 0.05 & I $1.04(0.62-1.74)$ & 0.86 \\
\hline $\begin{array}{l}\text { Wealth index } \\
\text { quintile }\end{array}$ & $\begin{array}{l}\text { Lowest } \\
\text { Second } \\
\text { Middle } \\
\text { Fourth } \\
\text { Highest }\end{array}$ & $\begin{array}{l}32(40.5) \\
36(42.9) \\
39(45.9) \\
41(44.1) \\
35(51.5)\end{array}$ & $\begin{array}{l}47(59.5) \\
48(57.1) \\
46(54.1) \\
52(55.9) \\
33(48.5)\end{array}$ & $\begin{array}{l}0.64(0.33-1.23) \\
0.70(0.37-1.34) \\
0.79(0.42-1.51) \\
0.74(0.39-1.39) \\
1\end{array}$ & $\begin{array}{l}0.18 \\
0.29 \\
0.49 \\
0.35\end{array}$ & $\begin{array}{l}1.05(0.49-2.22) \\
0.90(0.44-1.85) \\
0.95(0.46-1.93) \\
0.81(0.41-1.63) \\
1\end{array}$ & $\begin{array}{l}0.89 \\
0.78 \\
0.89 \\
0.57\end{array}$ \\
\hline Received ANC & $\begin{array}{l}\text { Yes } \\
\text { No }\end{array}$ & $\begin{array}{l}156(41.9) \\
27(73.0)\end{array}$ & $\begin{array}{l}216(58.1) \\
10(27.0)\end{array}$ & $\begin{array}{l}\text { I } \\
3.73(1.75-7.94)\end{array}$ & 0.03 & $\begin{array}{l}\text { I } \\
3.65(1.45-9.16)\end{array}$ & $0.006 *$ \\
\hline Place of birth & $\begin{array}{l}\text { Home } \\
\text { Health center } \\
\text { Hospital }\end{array}$ & $\begin{array}{l}23(56.1) \\
70(47.3) \\
90(40.9)\end{array}$ & $\begin{array}{l}18(43.9) \\
78(52.7) \\
130(59.1)\end{array}$ & $\begin{array}{l}1.84(0.94-3.61) \\
\text { I.29( }(0.85-1.97) \\
\mathrm{I}\end{array}$ & $\begin{array}{l}0.23 \\
0.07\end{array}$ & $\begin{array}{l}0.92(0.39-2.14) \\
1.23(0.76-1.98) \\
I\end{array}$ & $\begin{array}{l}0.84 \\
0.39\end{array}$ \\
\hline Mode of delivery & $\begin{array}{l}\text { Vaginal } \\
\text { Cesarean section }\end{array}$ & $\begin{array}{l}\text { I } 72(46.0) \\
\text { II (36.7) }\end{array}$ & $\begin{array}{l}207(54.0) \\
19(63.3)\end{array}$ & $\begin{array}{l}\text { I' } \\
0.68(0.31-1.17)\end{array}$ & 0.13 & $\begin{array}{l}\text { I } \\
0.75(0.37-\mid .5 I)\end{array}$ & 0.43 \\
\hline Birth outcome & $\begin{array}{l}\text { Alive } \\
\text { Dead }\end{array}$ & $\begin{array}{l}\text { I } 72(46.0) \\
\text { II (3I.4) }\end{array}$ & $\begin{array}{l}202(54.0) \\
24(68.6)\end{array}$ & $\begin{array}{l}\text { I } \\
0.53(0.25-1.13)\end{array}$ & 0.10 & $\begin{array}{l}\text { I } \\
0.47(0.20-1.07)\end{array}$ & 0.07 \\
\hline $\begin{array}{l}\text { History of } \\
\text { Hospital admission } \\
\text { during pregnancy }\end{array}$ & $\begin{array}{l}\text { Yes } \\
\text { No }\end{array}$ & $\begin{array}{l}31(5 \mid .7) \\
152(43.6)\end{array}$ & $\begin{array}{l}29(48.3) \\
197(56.4)\end{array}$ & $\begin{array}{l}1.38(0.80-2.39) \\
\text { । }\end{array}$ & 0.24 & $\begin{array}{l}1.26(0.58-2.69) \\
\text { I }\end{array}$ & 0.55 \\
\hline $\begin{array}{l}\text { Postpartum } \\
\text { depression }\end{array}$ & $\begin{array}{l}\text { Depressed } \\
\text { Not depressed }\end{array}$ & $\begin{array}{l}18(32.7) \\
155(48.3)\end{array}$ & $\begin{array}{l}37(67.3) \\
166(5 \mid .7)\end{array}$ & $\begin{array}{l}1.92(1.21-3.29) \\
1\end{array}$ & 0.006 & $\begin{array}{l}2.27(1.30-3.93) \\
\mathrm{I}\end{array}$ & $0.004^{*}$ \\
\hline
\end{tabular}

Notes: * a statistically significant variable at $p<0.05$ in multivariable logistic regression analysis.

also be an alternative explanation for women who have given birth by cesarean section receive better social, psychological, and nutritional support which ease recovery. The other factor could be the higher likelihood of a late resumption of sexual intercourse after cesarean delivery which alleviates physical and psychological pain. ${ }^{34}$ An additional reason that needs to be considered is the socio-economic factor as the majority of women who underwent cesarean delivery are more likely to be educated, affluent, or have better economic status. These factors have an improving effect on HRQoL, and this is supported by the study conducted in Sub-Saharan Africa. $^{35}$
Adequate antenatal care was also another factor for HRQoL in the current study. Women who had no ANC visits were more likely to have a lower mental HRQoL. This finding was supported by a study conducted in Rwanda. ${ }^{26}$ The reason for this finding was women who attend ANC allows health promotion, a good opportunity to be informed about pregnancy danger signs, and obstetric complications. Besides, receiving ANC facilitates early detection and management of pregnancy-related problems. We suggest that ANC is vital to improve the HRQoL for the women who give birth.

Finally, in this study women who had postpartum depression were more likely to have a lower-level mental HRQoL, 
Table 6 Binary and Multivariable Logistic Regression Analysis for Factors Associated with Physical HRQoL at Arba Minch Town in $2020(n=409)$

\begin{tabular}{|c|c|c|c|c|c|c|c|}
\hline Variables & Categories & $\begin{array}{l}\text { Lower PCS } \\
\text { HRQoL (\%) }\end{array}$ & $\begin{array}{l}\text { Higher PCS } \\
\text { HRQoL (\%) }\end{array}$ & COR $(95 \% \mathrm{Cl})$ & p-value & AOR $(95 \% \mathrm{Cl})$ & $p$-value \\
\hline $\begin{array}{l}\text { Wealth index } \\
\text { quintile }\end{array}$ & $\begin{array}{l}\text { Lowest } \\
\text { Second } \\
\text { Middle } \\
\text { Fourth } \\
\text { Highest }\end{array}$ & $\begin{array}{l}41(51.9) \\
40(47.6) \\
35(41.2) \\
36(38.7) \\
35(51.5)\end{array}$ & $\begin{array}{l}38(48.1) \\
44(52.4) \\
50(58.8) \\
57(61.3) \\
33(48.5)\end{array}$ & $\begin{array}{ll}\text { I.0I } & (0.53-1.94) \\
0.85 & (0.31-1.62) \\
0.66 & (0.34-1.25) \\
0.59 & (0.31-I .12) \\
I\end{array}$ & $\begin{array}{l}0.95 \\
0.64 \\
0.20 \\
0.11\end{array}$ & 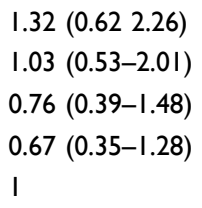 & $\begin{array}{l}0.42 \\
0.92 \\
0.42 \\
0.23\end{array}$ \\
\hline $\begin{array}{l}\text { Duration since } \\
\text { delivery }\end{array}$ & $\begin{array}{l}\leq 3 \text { Months } \\
>3 \text { Months }\end{array}$ & $\begin{array}{l}\text { II } 15(47.3) \\
72(43.4)\end{array}$ & $\begin{array}{l}128(52.3) \\
94(56.6)\end{array}$ & $\begin{array}{l}1.16(0.77-1.74) \\
1\end{array}$ & 0.24 & $\begin{array}{l}1.08(0.70-1.66) \\
\text { I }\end{array}$ & 0.91 \\
\hline Parity & $\begin{array}{l}\text { Prim para } \\
\text { Multipara }\end{array}$ & $\begin{array}{l}36(4 \mid .9) \\
|5|(46.7)\end{array}$ & $\begin{array}{l}50(58.1) \\
172(53.3)\end{array}$ & $\begin{array}{l}1.09(0.66-1.78) \\
1\end{array}$ & 0.21 & $\begin{array}{l}0.96(0.56-1.65) \\
1\end{array}$ & 0.90 \\
\hline $\begin{array}{l}\text { Mode of } \\
\text { delivery }\end{array}$ & $\begin{array}{l}\text { Vaginal } \\
\text { Cesarean section }\end{array}$ & $\begin{array}{l}198(52.2) \\
6(20.0)\end{array}$ & $\begin{array}{l}|8|(47.8) \\
24(80.0)\end{array}$ & $\begin{array}{l}I^{\prime} \\
0.22(0.11-0.68)\end{array}$ & 0.01 & $\begin{array}{l}\text { I } \\
0.34(0.13-0.88)\end{array}$ & $0.03 *$ \\
\hline $\begin{array}{l}\text { Place of } \\
\text { delivery }\end{array}$ & $\begin{array}{l}\text { Home } \\
\text { Health center } \\
\text { Hospital }\end{array}$ & $\begin{array}{l}20(48.8) \\
78(52.7) \\
89(40.5)\end{array}$ & $\begin{array}{l}21(51.2) \\
70(47.3) \\
131(59.5)\end{array}$ & $\begin{array}{l}0.85(0.42-1.7 I) \\
0.2 I(0.6 I-0.93) \\
I\end{array}$ & $\begin{array}{l}0.23 \\
0.07\end{array}$ & $\begin{array}{l}0.96(0.47-1.96) \\
0.64(0.4 I-1.02) \\
I\end{array}$ & $\begin{array}{l}0.92 \\
0.06\end{array}$ \\
\hline $\begin{array}{l}\text { Postpartum } \\
\text { depression }\end{array}$ & $\begin{array}{l}\text { Depressed } \\
\text { Not depressed }\end{array}$ & $\begin{array}{l}40(45.5) \\
147(45.8)\end{array}$ & $\begin{array}{l}48(54.5) \\
174(54.2)\end{array}$ & $\begin{array}{l}0.99(0.63-1.62) \\
1\end{array}$ & 0.25 & $\begin{array}{l}0.93(0.57-1.53) \\
\text { I }\end{array}$ & 0.80 \\
\hline
\end{tabular}

Notes: * a statistically significant variable at $p<0.05$ in multivariable logistic regression analysis.

and this finding is in agreement with findings from Nigeria, Kuwait, Carolina state, and Iran. ${ }^{32,36-38}$ The reason was depression is negatively associated with mental health, and depression by itself affects women's ability to function, relation with her child, interpersonal relationship, sleeping pattern, and social engagement, thus lowering the mental HRQoL. ${ }^{39}$

\section{Limitations}

The data may be subjected to recall bias and social desirability bias. Since the study was community-based we could not ascertain and measure variables like chronic disease and pregnancy and birth-related problems that could affect the quality-of-life.

\section{Conclusion}

The findings of this study demonstrated almost two-thirds of women had a lower level of health-related quality of life (HRQoL). In particular women's mental HRQoL showed severe compromise. Several factors were identified to be associated with lower HRQoL. Lower age, no formal education, not receiving $\mathrm{ANC}$, and having postpartum depression were found to have a negative association with overall or mental HRQoL. This implies the quality-of-life of postpartum women needs much attention. Policymakers, program planners, and other concerned bodies should consider measures to be taken to improve the quality-of-life of postpartum women focusing on maternal services like ANC \& improving educational status and particular attention needs to be paid to young women.

\section{Data Sharing Statement}

The data used to support the findings of this study are available from the corresponding author upon request.

\section{Ethical Consideration}

Ethical clearance was obtained from the Institutional Research Ethics Review Board (IRB) of Arba Minch University. Before the fieldwork, necessary communications about the overall purpose of the study were made with the town administrative bodies. Verbal assent was taken (for those aged $<18$ ) and permission was taken from families or health professionals if families are not available and written consent was taken (for those age 18 and above); after explaining the purpose of the study, the harm and the benefit, the confidentiality, and the rights of the subjects. To maintain confidentiality, no personal identifiers were used on data collection forms and the recorded data were not accessed by a third person, except the principal investigators. All recommended COVID-19 prevention measures were applied to protect the data. The suspected cases were linked with the nearby health 
facility COVID-19 task forces. Besides, this study was conducted following the Declaration of Helsinki, and all ethical and professional considerations were followed throughout the study to keep participants' data strictly confidential.

\section{Acknowledgment}

First and foremost, we would like to thank Arba Minch University, College of Medicine and Health Sciences, School of Public Health for providing us the opportunity to prepare this research. My deepest gratitude goes to the study participants, data collectors, and Arba Minch town health bureau staffs for their unreserved cooperation.

\section{Author Contributions}

All authors made a significant contribution to the work reported, whether that is in the conception, study design, execution, acquisition of data, analysis, and interpretation, or in all these areas; took part in drafting, revising, or critically reviewing the article; gave final approval of the version to be published; have agreed on the journal to which the article has been submitted, and agree to be accountable for all aspects of the work.

\section{Funding}

Arba Minch University supports this research financially. The university has no role in the design of the study, collection, analysis, and interpretation of the data, and in writing the manuscript.

\section{Disclosure}

The authors declare no conflicts of interest for this work and that there is no conflict of interest regarding the publication of this paper.

\section{References}

1. Soma-Pillay P, Nelson-Piercy C, Tolppanen H, Mebazaa A. Physiological changes in pregnancy. Cardiovasc J Afr. 2016;27 (2):89-94. doi:10.5830/CVJA-2016-021

2. Kumari P, Sharma R. Physiology And Management Of Normal Puerperium Through Ayurveda. 2018.

3. Graham W, Woodd S, Byass P, et al. Diversity and divergence: the dynamic burden of poor maternal health. Lancet. 2016;388 (10056):2164-2175. doi:10.1016/S0140-6736(16)31533-1

4. WHO. World Health Statistics 2019: Monitoring Health for the Sdgs, Sustainable Development Goals. WHO; 2019.

5. WHO. TRENDS in MATERNAL MORTALITY 2000-2017 Estimates by WHO, UNICEF, UNFPA, World Bank Group, and the United Nations Population Division. Geneva: World Health Organization; 2019.

6. Vanderkruik RC, Tuncalp O, Chou D, Say L. Framing maternal morbidity: WHO scoping exercise. BMC Pregnancy Childbirth. 2013;13:213. doi:10.1186/1471-2393-13-213
7. Chou D, Tuncalp O, Firoz T, et al. Constructing maternal morbidity towards a standard tool to measure and monitor maternal health beyond mortality. BMC Pregnancy Childbirth. 2016;16:45. doi:10.1186/s12884-015-0789-4

8. Tabassum Firoz DC, Peter D, Agrawal P, et al. Measuring maternal health: focus on maternal morbidity. Bull World Health Organ. 2013;91:794-796. doi:10.2471/BLT.13.117564

9. WHO. WHOQOL-BREF: Introduction, Administration, Scoring and Generic Version of the Assessment: Field Trial Version, December 1996. Geneva: World Health Organization; 1996.

10. Moller AB, Patten JH, Hanson C, et al. Monitoring maternal and newborn health outcomes globally: a brief history of key events and initiatives. Tropical Med Int Health. 2019;24(12):1342-1368. doi:10.1111/tmi. 13313

11. Gon G, Leite A, Calvert C, Woodd S, Graham WJ, Filippi V. The frequency of maternal morbidity: a systematic review of systematic reviews. Int $j$ Gynecol Obstetrics. 2018;141(Suppl 1):20-38. doi:10.1002/ijgo. 12468

12. Machiyama K, Hirose A, Cresswell JA, et al. Consequences of maternal morbidity on health-related functioning: a systematic scoping review. BMJ Open. 2017;7(6):e013903. doi:10.1136/bmjopen2016-013903

13. Tully KP, Stuebe AM, Verbiest SB. The fourth trimester: a critical transition period with unmet maternal health needs. Am J Obstet Gynecol. 2017;217(1):37-41. doi:10.1016/j.ajog.2017.03.032

14. Aö FÖ. Determination of the life quality and self-care ability of the mothers in post-partum period. JPMA. 2018;68(2):210-216.

15. Kohler S, Sidney Annerstedt K, Diwan V, et al. Postpartum quality of life in Indian women after vaginal birth and cesarean section: a pilot study using the EQ-5D-5L descriptive system. BMC Pregnancy Childbirth. 2018;18(1):427. doi:10.1186/s12884-018-2038-0

16. Korvenranta E, Linna M, Rautava L, et al. Hospital costs and quality of life during 4 years after very preterm birth. Arch Pediatr Adolesc Med. 2010;164(7):657-663. doi:10.1001/archpediatrics.2010.99

17. Zubaran C, Foresti K. Investigating quality of life and depressive symptoms in the postpartum period. $j$ Australian College Midwives. 2011;24(1):10-16. doi:10.1016/j.wombi.2010.05.002

18. Zaheri F, Nasab LH, Ranaei F, Shahoei R. The relationship between quality of life after childbirth and the childbirth method in nulliparous women referred to healthcare centers in Sanandaj, Iran. Electronic Phys. 2017;9(12):5985-5990. doi:10.19082/5985

19. Van der Woude DA, Pijnenborg JM, de Vries J. Health status and quality of life in postpartum women: a systematic review of associated factors. Eur J Obstet Gynecol Reprod Biol. 2015;185:45-52. doi:10.1016/j.ejogrb.2014.11.041

20. Rezaei N, Tavalaee Z, Sayehmiri K, Sharifi N, Daliri S. The relationship between quality of life and methods of delivery: a systematic review and meta-analysis. Electronic Phys. 2018;10(4):6596-6607. doi:10.19082/6596

21. John E, Ware J, Kristin K. SF-36 Health Survey Manual and Interpretation Guide. The Health Institute, New England Medical Cente; 1993.

22. Lins L, Carvalho FM. SF-36 total score as a single measure of health-related quality of life: scoping review. SAGE Open Medicine. 2016;4:2050312116671725. doi:10.1177/2050312116671725

23. Ware JE. SF-36 Physical and Mental Health Summary Scale: A User Manual and Interpretation Guide. Boston: the health Institute, New England Medical Center; 1993.

24. Tesfaye M, Hanlon C, Wondimagegn D, Alem A. Detecting postnatal common mental disorders in Addis Ababa, Ethiopia: validation of the Edinburgh Postnatal Depression Scale and Kessler Scales. J Affect Disord. 2010;122(1-2):102-108. doi:10.1016/j.jad.2009.06.020

25. Rezaei N, Azadi A, Zargousi R, Sadoughi Z, Tavalaee Z, Rezayati M. Maternal Health-Related Quality of Life and Its Predicting Factors in the Postpartum Period in Iran. Scientifica. 2016;2016:8542147. doi: $10.1155 / 2016 / 8542147$ 
26. Hitimana R, Lindholm L, Krantz G, et al. Health-related quality of life determinants among Rwandan women after delivery: does antenatal care utilization matter? A cross-sectional study. $J$ Health Popul Nutr. 2018;37(1):12. doi:10.1186/s41043-018-0142-4

27. Martinez-Galiano JM, Hernandez-Martinez A, Rodriguez-Almagro J, Delgado-Rodriguez M. Quality of Life of Women after Giving Birth: associated Factors Related with the Birth Process. J Clin Med. 2019;8 (3):324. doi:10.3390/jcm8030324

28. Hernandez-Martinez A, Rodriguez-Almagro J, Molina-Alarcon M, Infante-Torres N, Donate Manzanares M, Martinez-Galiano JM. Postpartum post-traumatic stress disorder: associated perinatal factors and quality of life. J Affect Disord. 2019;249:143-150. doi:10.1016/j. jad.2019.01.042

29. Angelini CR, Pacagnella RC, Parpinelli MA, et al. Quality of Life after an Episode of Severe Maternal Morbidity: evidence from a Cohort Study in Brazil. Biomed Res Int. 2018;2018:9348647. doi: $10.1155 / 2018 / 9348647$

30. Bai G, Korfage IJ, Mautner E, Raat H. Determinants of Maternal Health-Related Quality of Life after Childbirth: the Generation R Study. Int J Environ Res Public Health. 2019;16:18.

31. Derege Kebede AA, Shibre T, Negash A, Deyassa N. Tefera Beyero Health-related quality of life (SF-36) survey in Butajira, rural Ethiopia: normative data and evaluation of reliability and validity. Ethiop Med J. 2004.

32. Badr HE. Postpartum depression and health-related quality of life: a necessary assessment. Int J Family Commu Med. 2017;1(1). doi:10.15406/ijfcm.2017.01.00005
33. Tuncalp OSJ, Hindin MJ, Santos CA, et al. Education and severe maternal outcomes in developing countries: a multicountry cross-sectional survey. BJOG. 2014;121(Suppl. 1):57-65. doi:10.1111/1471-0528.12634

34. Nazanin AC, Hamlaci Y, Janani F, Sharifi N, Omidi F, Azadi A. Sexual Function and Quality of Life Among Postpartum Women: a Cross-Sectional Study. Int $J$ Womens Health Reproduction Sci. 2018;6(3):548

35. Ushie BAUE, Ajayi AI, Ajayi AI. Examining inequalities in access to delivery by cesarean section in Nigeria. PLoS One. 2019;14(8): e0221778. doi:10.1371/journal.pone.0221778

36. Darcy JM, Grzywacz JG, Stephens RL, Leng I, Clinch CR Arcury TA. Maternal depressive symptomatology: 16-month follow-up of infant and maternal health-related quality of life. $\mathrm{J} \mathrm{Am}$ Board Fam Med. 2011;24(3):249-257. doi:10.3122/ jabfm.2011.03.100201

37. Mortazavi F, Mousavi SA, Chaman R, Khosravi A. Maternal quality of life during the transition to motherhood. Iran Red Crescent Med J. 2014;16(5):e8443. doi:10.5812/ircmj.8443

38. Aishatu Y. Relationship between quality of life and postpartum depression among women in Northcentral, Nigeria. Highland Med Res J. 2017;17(1):11-18.

39. Justine Slomian GH. Consequences of maternal postpartum depression: a systematic review of maternal and infant outcomes. Women's Health. 2019;15:1-55.
International Journal of Women's Health

\section{Publish your work in this journal}

The International Journal of Women's Health is an international, peerreviewed open-access journal publishing original research, reports, editorials, reviews and commentaries on all aspects of women's healthcare including gynecology, obstetrics, and breast cancer. The

\section{Dovepress}

manuscript management system is completely online and includes a very quick and fair peer-review system, which is all easy to use. Visit http://www.dovepress.com/testimonials.php to read real quotes from published authors. 